\title{
PENGARUH PERENDAMAN AIR JERUK NIPIS TERHADAP KADAR FORMALIN DALAM IKAN ASIN TERI NASI
}

\section{THE EFFECT OF LIME WATER IMMERSION ON FORMALIN CONTENT IN SALTED ANCHOVY}

\author{
Amelia Handayani Burhan ${ }^{1 *}$, Yuli Puspito Rini ${ }^{2}$, Farisya Nurhaeni ${ }^{3}$ \\ ${ }^{* 1}$ Politeknik Kesehatan Bhakti Setya Indonesia, Jl. Janti Gendongkuning No.336, Yogyakarta \\ email: amelia_handayani@poltekkes-bsi.ac.id, Indonesia \\ ${ }^{2}$ Politeknik Kesehatan Bhakti Setya Indonesia, Jl. Janti Gedongkuning No.336, Yogyakarta \\ email: y_puspitorini@yahoo.com, Indonesia \\ ${ }^{3}$ Politeknik Kesehatan Bhakti Setya Indonesia, Jl. Janti Gedongkuning No.336, Yogyakarta \\ email: farisyanur@yahoo.co.id, Indonesia
}

\begin{abstract}
Background: The use of formalin as a preservative in salted fish is potentially harmful to the human body, for example in the salted anchovy. They are very popular for customers in Traditional Market of Yogyakarta. The acidic compound, like lime water, can reduce the concentration of formalin.

Objective: This study aims to determine the effect of immersion of lime water on formalin concentration in salted anchovy fish.

Methods: A total of 25 samples from five traditional markets of Yogyakarta city were tested using formalin kit test. Positive samples were treated with immersion of lime water with some concentration; 20, 40,60, 80, and $100 \%(\mathrm{v} / \mathrm{v})$. Determination of formalin concentration was done by acidimetric method using $0.955 \mathrm{~N}$ hydrochloride and methyl red indicator.

Results: Concentration of formalin before treatment is $1,397 \%$. The content of Formalin after the immersion treatment of lime water with concentration $20,40,60,80$, and $100 \%(\mathrm{v} / \mathrm{v})$ for 60 minutes was 1.094; 1,015; $0.712 ; 0.426$ and $0.283 \%(\mathrm{w} / \mathrm{w})$.

Conclusion: Based on the statistical test can be concluded that there is the influence of the concentration of immersion of lime water to formalin concentration in salted anchovy fish. The higher concentration of lime water can decrease formalin until $79.71 \%$.
\end{abstract}

Keywords: Acidimetric formalin, anchovy salted fish, lemon water, traditional market of Yogyakarta

\section{PENDAHULUAN}

Formalin merupakan bahan kimia tambahan yang berfungsi sebagai pengawet tetapi tidak diperbolehkan digunakan dalam bahan pangan/makanan. ${ }^{1}$ Formalin yang masuk ke dalam tubuh akan memengaruhi zat di dalam sel dan menekan fungsi sel yang dapat berakibat pada kematian sel, yang dapat menyebabkan keracunan, iritasi lambung, alergi, karsinogenik, dan mutagen. Walaupun sangat berbahaya bagi kesehatan, akan tetapi banyak penelitian yang menunjukkan bahwa banyak bahan pangan yang positif mengandung formalin, di antaranya susu, tahu, mie, ikan asin, dan ikan basah. ${ }^{2}$ Ikan asin adalah salah satu komoditi pangan protein yang memiliki nilai ekonomis dan digemari oleh masyarakat. Proses pengawetan ikan asin disinyalir menggunakan formalin, seperti yang ditemukan di pasar tradisional dan pasar modern Kota Semarang, ${ }^{3}$ Pasar Tradisonal Yogyakarta, ${ }^{4}$ Pasar Selasa, Pasar Sentral, dan Gelalel Kota Gorontalo, ${ }^{5}$ di mana 100\% sampel positif mengandung formalin. Berdasarkan hal tersebut, maka diperlukan 
upaya preventif bagi masyarakat sebelum mengonsumsi ikan asin yang sangat mungkin mengandung formalin.

Perebusan dan penambahan belimbing wuluh dalam sampel positif formalin terbukti dapat menurunkan kadar formalinnya. Penelitian serupa yang menggunakan belimbing wuluh dengan konsentrasi $60 \%$ dan lama perendaman 30 menit terbukti mampu menurunkan kadar formalin hingga $81,25 \% .{ }^{6}$ Asam sitrat dalam belimbing wuluh diduga memiliki peranan penting dalam pelepasan ikatan formalin.

Ikan asin teri nasi sangat diminati di Kota Yogyakarta dan banyak digunakan dalam pembuatan nasi kucing, salah satu makanan khas Yogyakarta. Peneliti menduga bahwa ikan asin teri nasi yang beredar di Yogyakarta memiliki peluang besar mengandung formalin sehingga diperlukan upaya pengolahan agar potensi tubuh teracuni formalin semakin kecil. Jeruk nipis juga mengandung asam sitrat. Oleh karena itu, peneliti menduga bahwa jeruk nipis dapat digunakan untuk menurunkan kadar formalin dalam ikan asin teri nasi yang beredar di pasar tradisional Yogyakarta.

\section{BAHAN DAN CARA PENELITIAN}

\section{Bahan dan Alat}

Bahan yang digunakan terdiri atas ikan asin teri nasi, Kit Test Formalin, jeruk nipis, akuades, indikator metil merah, hydrogen peroksida $10 \%$ PA, natrium hidroksida $1 \mathrm{~N} \mathrm{PA}$, dan $\mathrm{HCl} 0,95 \mathrm{~N}$ PA. Alat yang digunakan terdiri atas mortar dan stamfer (rrc), corong kaca (pyrex), buret, pipet volume, erlenmeyer (iwaki), labu takar, timbangan analitik (ohaus), pipet tetes (rrc), beaker glass (pyrex), dan oven.

\section{Sampling}

Sampel yang digunakan adalah 25 sampel yang didapatkan dari 5 Pasar Tradisional Yogyakarta di mana setiap pasar terdiri atas 5 titik lokasi pengambilan sampel. Pengumpulan sampel ikan asin dengan metode non probability sample dan teknik pengambilan sampel secara tidak acak, sehingga semua anggota populasi berkesempatan yang sama untuk terpilih menjadi sampel. Sampel selanjutnya diberi kode berdasarkan asal pasar yaitu A, B, C, $D$, dan $E$ dengan penomoran 1 sampai 5 .

\section{Identifikasi Formalin}

Identifikasi formalin dilakukan dengan menggunakan tes kit formalin. Proses identifikasi ini dilakukan dengan membandingkan perolehan warna sampel yang telah ditetesi reagen terhadap larutan kontrol yang mengandung formalin. Terbentuknya warna ungu menunjukkan sampel positif mengandung formalin.

\section{Perlakuan Perendaman Jeruk Nipis}

Perlakukan perendaman dilakukan dengan menggunakan sari jeruk nipis yang kemudian divariasi konsentrasinya yakni 20, 40, 60, 80, dan 100\% (v/v). Sampel ditimbang seksama 3 gram dan selanjutnya direndam masing-masing pada variasi konsentrasi jeruk nipis selama 60 menit. 


\section{Penetapan Kadar Formalin}

Sebanyak 3 gram sampel yang telah diberi perlakuan dihaluskan menggunakan mortar dan stamper. Kemudian, sampel yang telah halus dimasukkan ke dalam Erlenmeyer dan ditambahkan $25 \mathrm{ml}$ hidrogen peroksida $10 \%, 50 \mathrm{ml} \mathrm{NaOH} 1 \mathrm{~N}$, dan 3 tetes indikator metil merah. Larutan ini kemudian dititrasi dengan $\mathrm{HCl}$ 0,955 hingga terbentuk warna merah muda yang stabil. Hal yang sama dilakukan untuk larutan blangko. Replikasi dilakukan sebanyak 3 kali untuk setiap sampel dan blangko. Menurut Farmakope ${ }^{7}$, kadar formalin ditentukan dengan persamaan (1).

$\%$ Formalin $=\frac{\left(V_{b}-V_{s}\right) \times N \times B E}{m g \text { sampel }} \times 100 \%$ (1)

Keterangan:

$\%$ Formalin : kadar formalin (\%b/b)

$\mathrm{V}_{\mathrm{b}} \quad$ : Volume blangko $(\mathrm{mL})$

$\mathrm{V}_{\mathrm{s}} \quad$ : Volume sampel $(\mathrm{mL})$

$\mathrm{N}$ : Normalitas $\mathrm{HCl}(\mathrm{N})$

BE : Bobot Ekivalen $\mathrm{HCl}$ (grek)'

\section{Analisis Data}

Uji pengaruh konsentrasi perendaman jeruk nipis dilakuan dengan uji statistik. Analisis dilakukan menggunakan Frequencies untuk mengetahui normalitas data, uji One Way Anova, dan Test of Homogeneity of Variances untuk melihat homogenitas dari data yang peroleh.

\section{HASIL DAN PEMBAHASAN}

Uji kuantitatif formalin dalam sampel ikan asin teri nasi dilakukan dengan menggunakan pereaksi Tes Kit Formalin. Tabel 1 menunjukkan bahwa seluruh sampel teridentifikasi positif mengandung formalin yang ditunjukkan dengan terbentuknya warna ungu setelah sampel diberi reagen tes kit formalin. Hal ini menunjukkan bahwa diperlukan upaya preventif untuk mengurangi kemungkinan formalin dari ikan asin teri nasi terkonsumsi ke dalam tubuh konsumen. Pada sampel ikan asin teri nasi yang diuji positif mengandung formalin memiliki ciri-ciri putih, bersih, tidak dihinggapi lalat, dan tidak busuk lebih dari 1 bulan pada suhu kamar. Selanjutnya sampel dengan kode A5 dipilih sebagai perwakilan dalam uji rendaman sari jeruk nipis.

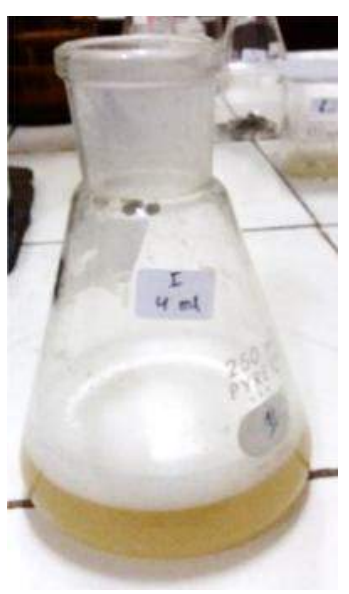

a

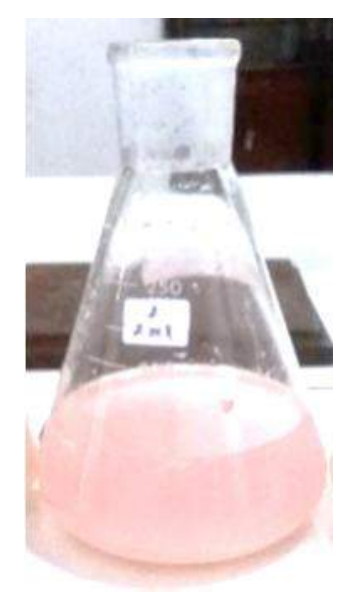

b
Gambar 1. Larutan Sampel sebelum (a) dan sesudah (b) titrasi 
Tabel 1. Hasil Kualitatif Dengan Test Kit Formalin

\begin{tabular}{clcl}
\hline \multirow{2}{*}{ Kode } & \multicolumn{2}{c}{$\begin{array}{c}\text { Penambahan Reagen A } \\
\text { dan B }\end{array}$} & \multirow{2}{*}{$\begin{array}{c}\text { Intensitas } \\
\text { warna }\end{array}$} \\
\cline { 2 - 3 } & \multicolumn{1}{c}{ Sebelum } & Sesudah & \\
\hline (1) & \multicolumn{1}{c}{$(2)$} & $(3)$ & \\
\hline A1 & Putih & Ungu & + \\
A2 & Coklat & Ungu & + \\
A3 & Putih & Ungu & ++ \\
A4 & Putih & Ungu & +++ \\
A5 & Putih & Ungu & +++ \\
B1 & Putih & Ungu & ++ \\
B2 & Putih & Ungu & ++ \\
\hline B3 & Putih & Ungu & +++ \\
B4 & Putih & Ungu & +++ \\
B5 & Putih & Ungu & +++ \\
C1 & Putih & Ungu & +++ \\
C2 & Putih & Ungu & ++ \\
C3 & Putih & Ungu & +
\end{tabular}

\begin{tabular}{|c|c|c|c|}
\hline \multirow[t]{2}{*}{ Kode } & \multicolumn{2}{|c|}{$\begin{array}{c}\text { Penambahan Reagen A } \\
\text { dan B }\end{array}$} & \multirow{2}{*}{$\begin{array}{c}\text { Intensitas } \\
\text { warna }\end{array}$} \\
\hline & Sebelum & Sesudah & \\
\hline (1) & (2) & (3) & (4) \\
\hline $\mathrm{C} 4$ & Putih & Ungu & +++ \\
\hline C5 & Putih & Ungu & ++ \\
\hline D1 & Putih & Ungu & ++ \\
\hline D2 & Putih & Ungu & +++ \\
\hline D3 & Putih & Ungu & +++ \\
\hline D4 & Putih & Ungu & ++ \\
\hline D5 & Putih & Ungu & +++ \\
\hline E1 & Putih & Ungu & +++ \\
\hline E2 & Putih & Ungu & + \\
\hline E3 & Putih & Ungu & + \\
\hline E4 & Putih & Ungu & + \\
\hline E5 & Putih & Ungu & ++ \\
\hline Kontrol & $\begin{array}{l}\text { Tidak } \\
\text { berwarna }\end{array}$ & Ungu & +++ \\
\hline
\end{tabular}

Keterangan : +: ungu muda; ++: ungu; +++: ungu pekat

Penetapan kadar formalin dalam sampel dilakukan dengan menggunakan metode asidimetri. Larutan baku atau larutan standar yang digunakan adalah $\mathrm{HCl} 0,955 \mathrm{~N}$ dengan indikator metil merah. Dalam metode ini, digunakan larutan blangko yang digunakan untuk mengurangi kesalahan yang disebabkan oleh reaktan, pelarut, atau kondisi tertentu.

Titrasi asidimetri dalam penetapan kadar formalin merupakan jenis titrasi kembali, yaitu titrasi yang dilakukan terhadap sisa pereaksi berlebih dalam hal ini $\mathrm{NaOH}$. Penambahan $\mathrm{H}_{2} \mathrm{O}_{2}$ atau hidrogen peroksida dalam titrasi bertujuan mengkatalis formalin menjadi asam karboksilat, yang selanjutnya asam karboksilat tersebut bereaksi dengan $\mathrm{NaOH}$ membentuk garam. Sisa $\mathrm{NaOH}$ inilah yang akan habis bereaksi dengan larutan $\mathrm{HCl}$. Di mana titik akhir titrasi teramati dengan adanya perubahan warna larutan dari kuning menjadi muda (Gambar 1).

$\mathrm{HCOH}(\mathrm{aq})+\mathrm{H}_{2} \mathrm{O}_{2}(\mathrm{aq}) \rightarrow \mathrm{HCOOH}(\mathrm{aq})+$ $\mathrm{H}_{2} \mathrm{O}(\mathrm{I})$

$\mathrm{HCOOH}(\mathrm{aq})+\mathrm{NaOH}(\mathrm{aq}) \rightarrow \mathrm{HCOONa}(\mathrm{aq})$

$+\mathrm{H}_{2} \mathrm{O}(\mathrm{I})$

$\mathrm{NaOH}(\mathrm{aq}) /$ sisa $+\mathrm{HCl}(\mathrm{aq}) \rightarrow \mathrm{NaCl}(\mathrm{aq})+$ $\mathrm{H}_{2} \mathrm{O}(\mathrm{I})$

Tabel 2. Kadar formalin dalam ikan asin teri nasi sebelum perlakuan perendaman

\begin{tabular}{|c|c|c|}
\hline $\begin{array}{l}\text { Replikasi } \\
\text { ke- }\end{array}$ & $\begin{array}{c}\text { Berat } \\
\text { Sampel }\end{array}$ & $\%$ Formalin \\
\hline 1 & $3000,1 \mathrm{mg}$ & $1,35 \%$ \\
\hline 2 & $2999,9 \mathrm{mg}$ & $1,35 \%$ \\
\hline 3 & $3000,0 \mathrm{mg}$ & $1,45 \%$ \\
\hline Rerata k & ar formalin & $1,397 \%$ \\
\hline
\end{tabular}

Tabel 2. menunjukkan hasil persentase kadar formalin (b/b) dalam ikan asin teri nasi sebelum perlakukan yaitu 1,397\%. Angka ini bermakna bahwa dalam 100 gram ikan asin teri nasi mengandung 1,397 gram formalin. 


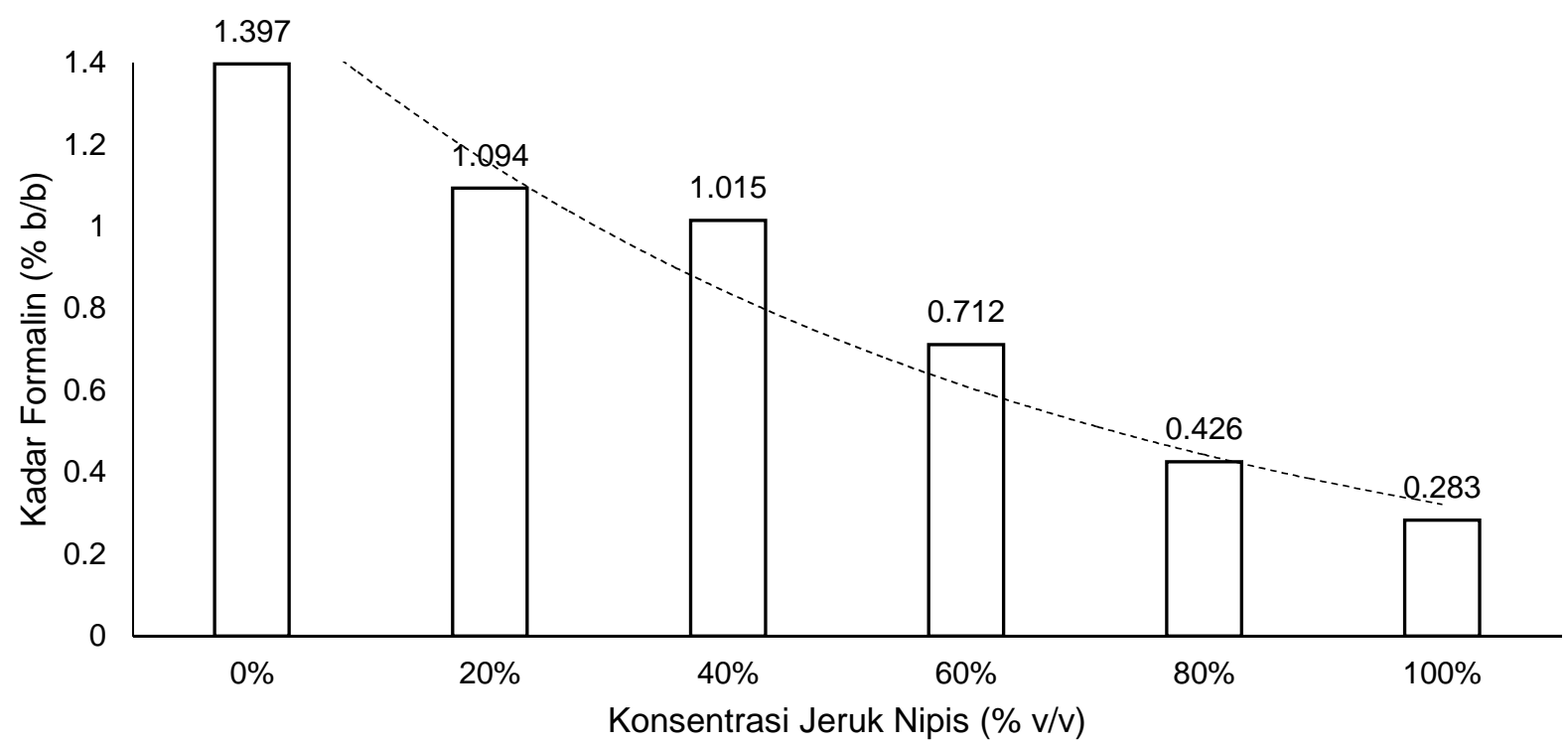

Gambar 2. Pengaruh variasi konsentrasi jeruk nipis terhadap kadar formalin dalam ikan asin teri nasi berformalin

Angka ini tinggi mengingat bahwa makanan tidak boleh mengandung formalin.

Upaya penurunan kadar formalin dilakukan dengan merendam 3 gram sampel ke dalam larutan jeruk nipis dengan variasi konsentrasi 20, 40, 60, 80, dan 100\% (v/v) selama 60 menit. Gambar 2 menunjukkan hasil penetapan kadar formalin setelah perlakukan perendaman. Terlihat bahwa ada penurunan kadar formalin seiring dengan penambahan konsentrasi larutan jeruk nipis yang digunakan untuk merendam sampel berformalin. Persentase penurunan mulai dari $21,01 \%$ untuk konsentrasi jeruk nipis $20 \%(\mathrm{v} / \mathrm{v})$ hingga tertinggi mencapai $79,91 \%$ untuk konsetrasi jeruk nipis 100\% (v/v). Penurunkan kadar formalin dalam ikan asin teri nasi disebabkan oleh kuat lemahnya asam organik yang terdapat dalam jeruk nipis.
Uji pengaruh konsentrasi perendaman sari jeruk nipis terhadap ikan asin teri nasi selanjutnya dilakukan uji statistik. Analisis yang pertama dilakukan menggunakan Frequencies untuk mengetahui normalitas data.

Suatu data dikatakan normal jika hasil nilai skewness terhadap standar eror of skewness dan hasil bagi kurtosis terhadap standar eror of kurtosis. Nilai yang di peroleh masuk pada range -2 sampai +2 jadi data dikatakan normal. Selanjutnya dilakukan uji One Way Anova. Untuk melihat homogenitas data dapat dilihat pada Test of Homogenity of Variances dari data yang peroleh Sig 0,177, dikatakan homogen jika $>0,05.0,177>0,05$ data homogen.

Hasil uji Anova didapat hasil 0,000< 0,05 artinya ada pengaruh perendaman sari jeruk nipis terhadap kadar formalin pada ikan 
asin teri nasi sehingga dilihat secara keseluruhan dikatakan ada pengaruh perendaman sari jeruk nipis terhadap kadar formalin pada ikan asin teri nasi. Hasil uji beda antara kadar formalin pada perendaman sari jeruk nipis baik sebelum perlakuan dengan setelah perlakuan, menunjukkan konsentrasi yang hasilnya tidak ada perbedaan yang signifikan yaitu pada konsentrasi $20 \%$ terhadap $60 \%$, konsentrasi $40 \%$ terhadap $60 \%$, konsentrasi $60 \%$ terhadap $80 \%$, konsentrasi $80 \%$ terhadap $100 \%$. Konsentrasi formalin sebelum perendaman menunjukkan antara kadar ada yang hasilnya yang berbeda tidak signifikan pada konsentrasi $20 \%$ terhadap $40 \%$ dengan $0,180<0,05$ dapat dilihat pada Post Hoc Test.

\section{KESIMPULAN}

Seluruh ikan asin teri nasi yang dijadikan sampel ikan asin teri nasi dari pasar tradisional Yogyakarta positif mengandung formalin. Upaya preventif sebelum ikan asin teri nasi dikonsumsi adalah dengan merendam teri nasi menggunakan sari atau larutan jeruk nipis. Hal ini berdasarkan penilitian bahwa terdapat pengaruh signifikan perenadam sari jeruk nipis terhadap penurunan kadar formalin dalam ikan asin teri nasi dengan nilai tertinggi perununan mencapai $79,71 \%$.

Diperlukan penelitian lebih lanjut untuk menemukan waktu efektif perendaman agar seluruh residu formalin dalam ikan asin teri nasi dapat hilang $100 \%$.

\section{TERIMA KASIH}

1. Dra. Yuli Puspito Rini, M.Si, Direktur Politeknik Kesehatan Bhakti Setya Indonesia, email: y_puspitorini@yahoo.com

2. Nur Ismiyati, M.Sc.Apt., Kaprodi D-3 Farmasi, Politeknik Kesehatan Bhakti Setya Indonesia, email: nur_is@yahoo.com

3. Resmi Aini, M.Sc., Ketua LPPM Politeknik Kesehatan Bhakti Setya Indonesia, email: resmiaini@gmail.com

4. Ayu Wulansari, A. Md., Apt, sebagai teknisi pengumpulan data penelitian, email: ayu wulansari@gmail.com

\section{KEPUSTAKAAN}

1. Menkes. 1988. Peraturan Menteri Kesehatan Republik Indonesia Nomor: 722/MENKES/PER/IX/88 Tentang Bahan Tambahan Makanan Menteri Kesehatan Republik Indonesia.

2. Cahyadi, Wisnu. Analisis \& Aspek Kesehatan Bahan Tambahan Pangan. 2012. Jakarta. Bumi Aksara.

3. Purba, W.K.D. Hanani D. Y. \& Yunita D. N.A. Studi Identifikasi Kandungan Formalin pada Ikan Teri Nasi Asin di Pasar Tradisional dan Pasar Modern Kota Semarang. 2015. JKM. Volume. 3. (3). Hal 831- 841.

4. Rini. Y.P. Setiyawan. H. Burhan. A.H. Sumarlini. T. \& Harmawati. Uji Formalin, Kandungan Garam dan Angka LempengTotal Bakteri pada Berbagai Jenis Ikan Asin yang Beredar di Pasar Tradisional Yogyakarta. 2017. Jurnal Pendidikan Sains UNIMUS. Volume 5. (1). Hal 1-9.

5. Abdullah, S. Uji Kuantitatif Kandungan Formalin Pada Ikan Asin yan Dijual di Pasar Sentral Kota Gorontalo. 2013. Karya Tulis IImiah. Gorontalo. Universitas Nergi Gorontalo 
6. Wikanta,W. Abdurrajak. Y, Sumarno, \& Amin. M. Pengaruh Penambahan Belimbing Wuluh (Averrhoa bilimbi L.) dan Perebusan Terhadap Kadar Residu Formalin dan Profil Protein Udang Putih (Letapenaeus vannamei) Berformalin serta Pemanfaatannya sebagai Sumber Pendidikan Gizi dan Keamanan Pangan pada Masyarakat. Prosiding Seminar Nasional VII Pendidikan Biologi. 2011. Volume 8. (1). Hal. 7684.

7. Department Kesehatan RI. Farmakope Indonesia Edisi IV. Jakarta. Depkes RI. 1995 